\title{
Introduction to Part 1
}

Even though, in general, our conception of permanent neutrality is scarcely understood by delegations of the Third World to the UN, we have so far enjoyed a favourable bias, based, on the one hand, on the humanitarian tradition of our country, and, on the other, on the international role played by Geneva. It is to be feared that this image might deteriorate in the future and that our neutrality might be accused of being a hypocritical screen for making good investments and doing good business with the 'racists' of Pretoria. ${ }^{1}$

The words of Bernard Turrettini, ambassador at the Office of the Permanent Observer of Switzerland to the UN, in February 1968 anticipated a change in the international perception of Switzerland's foreign policy in sub-Saharan Africa. As most former colonies had achieved independence and East-West tensions had started to relax in the late 196os, the independence wars in the Portuguese colonies were increasingly in the national and international spotlight. The fight against colonialism and white minority rule was the main issue uniting different African regimes. Most of the newly independent African and Asian states supported the struggle of African liberation movements politically, and in some cases materially. From the late 196os onwards, Afro-Asian criticism of white minority rule, voiced mainly at the UNGA and the OAU, became increasingly forceful. It also began to target Western states that were accused of collaborating with the racist regimes in Southern Africa.

While the political leaders of the Soviet Union, the PRC, and member states of the Eastern bloc spoke out for national liberation and provided Southern African liberation movements with arms and military training, the Western bloc's position was less clear-cut. Although there was widespread agreement that the days of colonialism and racist oppression were over, Cold War considerations prevented many governments from paying more than lip service to the principle of self-determination. The South African regime's insistence on its function as a bulwark against Communist liberation movements in the region, the strategic importance of the Cape Route, and its production of essential mineral resources helped to contain criticism of its Apartheid policy. ${ }^{2}$

1 Letter from Bernard Turrettini, ambassador at the Office of the Permanent Observer of Switzerland to the United Nations, to Federal Councillor Willy Spühler, 20.02.1968, p. 3, SFA E2003A\#1980/85\#1971*.

2 Evans, "The Great Simplifier", pp. 140-146. 
Portugal was a founding member of NATO and considered important for the protection of the organisation's southern flank and for stability in Southern Africa. Strong economic and military ties, most importantly the US Lajes airbase on the Portuguese Azores, prevented the US, British, French, and West German governments from publicly criticising the Portuguese regime. The governments of some small Western European states, notably those of Norway, Denmark, and the Netherlands, were more critical and in the 1970s advocated pressuring Portugal, through NATO, to change its colonial policy. However, on the whole, the Estado Novo regime remained well integrated in the Western alliance until the Carnation Revolution in April $1974 .^{3}$

Minority rule in Southern Africa and many Western governments' tolerance of it mobilised numerous civil society actors. As a part of the global protest movement after 1968, student groups, Third World activists, members of labour movements and Social Democratic parties, and religious organisations, such as the ecumenical WCC, supported the struggle of Southern African liberation movements and called for an end to racial oppression in the region. At the same time, they challenged their own governments to take a stand against white minority rule and to stop economic and military collaboration with regimes engaged in armed conflicts. ${ }^{4}$ As the debate about national liberation in Southern Africa became increasingly heated, Switzerland's economic role in the region drew much critical attention. This started to undermine the credibility and respectability of the country's policy of neutrality and put Swiss foreign policymakers on the defensive.

The intensification of the conflict over national liberation in Southern Africa in the late 196os and early 1970s was part of much bigger changes in international relations along East-West and North-South lines that challenged Switzerland's foreign policy. The late 196os marked the beginning of a transformation in East-West relations. The Cold War crises in Berlin and Cuba in the early 196os had brought home the dangers of an escalation of the superpower conflict in the nuclear age. As a result, Western European states took a series of steps to decrease international tensions and improve their relations with the USSR. In 1966, French President Charles de Gaulle withdrew from NATO's unified military command and visited Moscow. More importantly, Willy Brandt's Social Democratic government, which came into power in the FRG in late 1969, intensified the country's new Ostpolitik (policy towards the East). This would

3 See notably Rui Lopes, "Accommodating and Confronting the Portuguese Dictatorship within NATO, 1970-4", The International History Review 38:3 (2016), pp. 305-326.

4 See notably Kuhn, "Liberation Struggle and Humanitarian Aid"; Klimke, Scharloth, 1968 in Europe; Suri, Power and Protest. 
lead to the recognition of West Germany's territorial borders as inherited from the Second World War and to the mutual recognition of the two German states in late 1972. The Western European challenges to US dominance were mirrored in the Eastern bloc, although to a lesser degree. In March 1969, the Warsaw Pact renewed its call for a Pan-European security conference that, for the first time, did not exclude the US, and thereby launched the CSCE negotiations that would begin in 1972. The administration of Republican Richard Nixon, who entered office in early 1969, had the job of reacting to the relative decline of US power as the Soviet Union's strategic military forces approached those of the US, and to European wishes for reduced political tensions and increased economic cooperation with the Eastern bloc. Nixon and his National Security Advisor, Henry Kissinger, initiated direct back channel contact with the UssR. The two superpowers opened negotiations on arms controls, notably at the Strategic Arms Limitation Talks (SALT), and signed an interim agreement, known as SALT I, in May 1972 in Moscow. This first summit meeting between Nixon and Leonid Brezhnev was followed by a second conference in Washington in June 1973. The US administration also made efforts to improve relations with the PRC, which culminated in Nixon's China visit in February 1972. ${ }^{5}$

In parallel to the establishment of Détente, changes were underway in North-South relations. As decolonisation accelerated after the Second World War, the newly independent states in the global South began to organise themselves and create a common front to further their interests. In 1955, Asian and other Third World leaders met in Bandung, Indonesia, where they emphasised Third World cooperation, the liberation of colonial territories, and a neutralist foreign policy removed from superpower dominance. On these principles, the Non-Aligned Movement (NAM) was officially founded in 1961. In the economic sphere, during the first UN Conference on Trade and Development (UNCTAD) in 1964, developing countries formed the $\mathrm{G}_{77}$ group, whose membership overlapped with that of the NAM. They demanded more equality in North-South economic relations. By the early 1970s, Third World states formed a bloc that acted confidently on the international stage. ${ }^{6}$

5 See Raymond L. Garthoff, Détente and Confrontation. American-Soviet Relations from Nixon to Reagan, Washington, DC: The Brookings Institution, revised edition 1994; Jussi M. Hanhimäki, "Détente in Europe, 1962-1975", in Leffler, Westad, The Cambridge History of the Cold War. Volume II: Crises and Détente, pp. 198-218; Robert D. Schulzinger, "Détente in the NixonFord Years, 1969-1976", in Leffler, Westad, The Cambridge History of the Cold War. Volume II: Crises and Détente, pp. 373-394.

6 See notably Garavini, After Empires; Mazower, Governing the World; Jürgen Dinkel, "Third World Begins to Flex its Muscles'. The Non-Aligned Movement and the North-South Conflict during the 1970s", in Bott et al., Neutrality and Neutralism in the Global Cold War, pp. 108-123. 
In order to prevent international isolation in a context of East-West rapprochement, growing Third World political power, and European integration, Swiss foreign policymakers recognised the need for a more outward-looking position and adopted a more active approach to foreign policy. The experience of terrorism by left-wing Palestinian and Brazilian organisations, respectively, during the 1969-1970 attacks on an El Al plane at Zürich airport and the explosion of one and hijacking of another Swissair plane, and the kidnapping of the Swiss ambassador in Rio in 1970-1971, also contributed to the awareness that neutrality alone was not sufficient to protect Switzerland's standing in the Third World. This realisation resulted in a number of limited steps in some areas-notably Switzerland's active participation in the CSCE negotiations, the government's 1971 decision to join the UN, and the recognition of North Vietnam and North Korea in 1971 and 1974, respectively. ${ }^{7}$ Yet, despite the considerable political pressure exercised by Afro-Asian leaders (chapter 2) and part of Switzerland's civil society (chapter 3), the Swiss government resisted similar openings in Southern Africa, as it was unwilling to compromise its economic relations with Portugal and South Africa. This significantly impaired the image of Switzerland's neutrality in sub-Saharan Africa, especially as neutral Sweden presented an alternative model of a neutrality policy that was more attuned to Third World issues.

7 See Bott, Schaufelbuehl, "Switzerland and Détente"; Guttmann, The Origins of International Counterterrorism. 